\title{
Outlining NHRD as Practiced in Malaysia in its National Planning Context
}

\author{
Udaya Mohan Devadas ${ }^{1 *}$ \\ ${ }^{1}$ Department of Human Resources Management, University of Kelaniya, Sri Lanka \\ *Corresponding Author: mohanudaya395@gmail.com
}

\begin{abstract}
National Human Resource Development (NHRD) has been an emerging research agenda that reshaped the traditional view of HRD. NHRD literature adds many country case studies in building NHRD theory. Malaysia as a progressing country implements key programs relating to human resource development. Thus, before undergoing a detailed study into NHRD planning and execution, it is worthwhile to study the NHRD planning context, content and focus of, and term/s used for NHRD in Malaysia. A qualitative research design, using grounded theory method for data analysis was employed in this investigation. It was found that Malaysia's NHRD planning system is well established to include people development missions that aimed at national development, especially economic development, evolved gradually to Human Capital Development (HCD)as currently in use. This revelation is significant in bridging the NHRD theory gap within Malaysia's context and help NHRD theory building process. Further, this new insight will help policy makers to take decisions regarding Malaysia's NHRD in a more focused manner.
\end{abstract}

Keywords: Malaysia National Planning, Malaysia Plan, Malaysia’s HRD, Malaysia, National Human Resource Development

\section{INTRODUCTION}

HRD is a research agenda, started in 2001 to discuss the people development issues at national level, other than corporate organizational level. Mclean (2004) highlighted that the recently developed nations, transitioning and developing nations practices HRD at higher levels other than corporate organizational levels. However, the major domain of HRD remains only within corporate organizations (Mclean, 2004; Devadas et.al. 2010). Most of the HRD related problems, faced at organizational level, are unresolvable since the root cause for such problems have been rooted at a higher level. NHRD deals with such higher level or macro level HRD issues. NHRD started its research agenda, developing country case studies. This study contributes to NHRD research by studying NHRD in Malaysia. Malaysia is a vibrant country, having well established national policy and planning system to drive the country's development. In its national planning context, there is evidence of NHRD practices, yet Malaysia had not identified such HRD practices as NHRD until Devadas et. al. conceptualized such evidence as Malaysia's NHRD in 2016 which considered a planning period from 1950 to 2010 . This current study is an extension of conceptualizing the meaning of NHRD in Malaysia covering a period from 1950 to 2030. Hence, this study has two major phases; generating research outcomes for the period from 2011 to 2030 and integrate it with the study findings of 2016 to conceptualize Malaysia's NHRD for all time (from 1950 to 2030). This study aimed at answering the research questions of: what are the major challenges, faced by Malaysia 
that led NHRD? What is the focus of Malaysia's NHRD? What is the content of NHRD in Malaysia? And what are the term/s used for NHRD in Malaysia?

\section{Background of the Study}

Malaysia has a land area of approximately $330,345 \mathrm{~km}^{2}$, with about $8,840 \mathrm{~km}$ of coastline and over 879 islands (FAOU, 2020). Malaysia, together with its territorial waters lie between $0^{\circ}$ $51^{\prime} \mathrm{N}$ and $7^{\circ} 33^{\prime} \mathrm{N}$, and $98^{\circ} 01^{\prime} \mathrm{E}$ and $119^{\circ} 30^{\prime}$ E. It has 13 states and three Federal Territories. Eleven of the states and two of the Federal Territories (of Kuala Lumpur and Putrajaya) are in Peninsular Malaysia, and these are separated by the South China Sea from the states of Sabah and Sarawak in the island of Borneo. The Federal Territory of Labuan consisting of the island of Labuan is located off the coast of western Sabah (FAOU, 2020).

Malaysia is a multi-ethnic and multi-religious society consisting of a majority of Muslim population. Malaysia's total population is around 37 million in the year 2019 with a population growth rate of $0.4 \%$. Out of that, $69.6 \%$ of Bumiputra, $22.6 \%$ of Chinese, $6.8 \%$ of Indians and 1.0 of other category have been estimated in the year 2020 (Department of Statistics Malaysia $)^{1}$ Malaysia's most valuable mineral resources are; reserves of petroleum and natural gas, metallic ores such as Tin, bauxite (aluminum), copper, iron, manganese, antimony, mercury, and gold (Britannica) ${ }^{2}$.

Currently, Malaysia is experiencing its long journey after the vision 2020, laid down in 1991 with the tabling of the Sixth Malaysia plan to addressed nine national challenges: establishing a united Malaysian nation made up of one Bangsa Malaysia (Malaysian Race); creating a psychologically liberated and developed Malaysian society; fostering and developing a mature democratic society; establishing a fully moral and ethical society; establishing a matured liberal and tolerant society; establishing a

\footnotetext{
${ }^{1}$ https://www.dosm.gov.my/v1/index.php?r=column/ cthemeByCat\&cat $=155 \&$ bul_id $=$ OVByWjg5YkQ3M WFZRTN5bDJiaEVhZz09\&menu_id=L0pheU43N WJwRWVSZklWdzQ4TlhUUT09\#: :text=Malaysia'
}

scientific and progressive society; establishing a fully caring society; ensuring an economically just society, in which there is a fair and equitable distribution of the wealth of the nation; and establishing a prosperous society with an economy that is fully competitive, dynamic, robust and resilient. After achieving some of the areas of Malaysia's vision 2020, National Automaton Policy (NAP) was laid down in the year 2014 and an updated version of NAP was again launched in 2020 which maintains and enhances NAP- 2014. NAP-2020 aims at making Malaysia a regional leader in automotive manufacturing, engineering and technology, and to ensure sustainable development of the local automotive industry. The twelfth Malaysia plan is to be tabled in March 2021.

\section{Justifying the Need of NHRD to Malaysia}

In resolving these national challenges, the need and the role of HRD have been clearly highlighted, and the importance of nation's HRD has been properly recognized (Economic Planning Unit, 2011). In detailing about the strategic initiatives to economic development, a former prime minister of Malaysia, Mahathir Mohamad has stressed on the importance of HRD:

... I do believe that the narrowing of the ethnic income gap, through the legitimate provision of opportunities, through a closer parity of social services and infrastructure, through the development of the appropriate economic cultures and through full human resource development, is both necessary and desirable.... (International Business Publication USA, 2008, p.232)

In addition, the awareness of and the emphasis on NHRD within Malaysia have been realized in its practice. In the new NAP, human capital development has been

s\%20population\%20in\%202020\%20is,to\%203.0 $\% 20$ million\%20(2020). Accesses

${ }^{2}$ https://www.britannica.com/place/Malaysia/Res ources-and-power 
recognized as the second major strategy out of the three ${ }^{3}$. In the NAP 2014 plan, the third trust; "accelerating human capital development for advanced nation' also represents NHRD missions. In the eleventh Malaysia plan, the third trust- accelerating human capital development for advance nation (Malaysia, 2011) has shown successful progress in the areas of improving labour market efficiency, transforming TVET, strengthening lifelong learning for skills, and improving quality of education. human capital in the vision 2020, Malaysia's commitments for NHRD can be seen when reading the strategic approaches of creating an economically just society: "In order to achieve this economically just society, we must escalate dramatically our programs for national human resource development..." (International Business Publication USA, 2008, p.232). Continuing to realize the goals of vision 2020, in the FORWARD of the Ninth Malaysia plan that covered a period from 2006 to 2010, people's capability and the character of country's people have been considered as the most important factor in becoming a developed nation (Malaysia, 2009). In the same page, however, it has been identified that Malaysia has the urgency to adopt a holistic Human Capital Development encompassing not only knowledge and skills but ethical values, progressive minds and cultural awareness (Malaysia, 2009).

Even in its latest national policy, the 'New Economic Model (NEM), laid down in February 2010, launched in March 2010 to cover the period until 2020 gives a high priority in nation's HRD. The National Economic Advisory Council (NEAC) in Malaysia has identified and analyzed most critical factors to sluggish economic growth. They are: absence of private investment; difficulties of doing business; low value-added industries; stagnating productivity growth; lack of appropriately skilled human capital; insufficient innovation and creativity; and lowskilled jobs (Mehan, 2011). Accordingly, three out of seven critical factors are directly related to the country's HRD. This is a clear evidence for

${ }^{3}$ https://www.miti.gov.my/index.php/pages/view/nap 2020 the critical shortage and the importance of national level HRD to Malaysia. As highlighted in the NEM, the competitive loss of Malaysia in high-skilled versus lowskilled dichotomy is presented in Figure 01. Accordingly, Malaysia is far behind in dealing with a 'competitive' workforce among the regional giants.

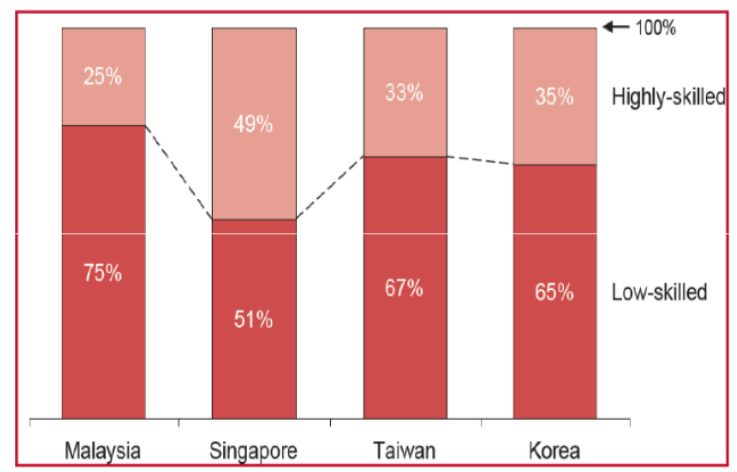

Figure 01: Highly-skilled and low-skilled labour $(2007 ; \%)$

Source: EPU, World Bank, extracted from New Economic Model for Malaysia Part 1, 2010, p.51

This low and high skill issue still exists according to a research done by Malaysia Industrial Development Financial Berhad (MIDF) that mentins that for every 100 jobs offered in 2018, 89 were for low-skilled jobs, seven for medium-skilled jobs and four highskilled jobs ${ }^{4}$. Except for the low -skilled labour problem, in the NEM Malaysia has identified a few other critical limitations of its HRD: (1) The share of labour force with tertiary education needs further improvements; (2) Labour productivity of Malaysia in recent years (from 1998-2007) is considerably low and has declined while some other countries like China and India has increased their labor productivity; (3) Insufficient efforts to create innovation and creativity; (4) Leaving talents instead of attracting and retaining them due to loss of Malaysian talents and steady decline of

${ }^{4}$ https://www2.staffingindustry.com/row.../Editor ial/Daily-News/Malaysia-Low-skilled-jobsdominate-labour-market-in-2018-49317 
expatriates; (5) lack in quality of Malaysian students; (6) Lower proportion of technical and science streams to Arts stream; (7) and decline in producing vocational and technical graduates leading to the production of the talent that is not in high demand (NEAM, 2010). With these highlighted critical issues, it's clear that Malaysia believes in HRD in reaching its development goals. Minister of Human Resources in Malaysia, proves this stating that: "the government's primary focus and most important task today is to develop and secure human resources of outstanding knowledge, skills, creativity, innovation, energy and discipline" (Mehan,2011).

NEM comprised of four major pillars for a national transformation: 1 Malaysia, Government Transformation Programme (GTP), Economic Transformation Programme (ETP), and the $10^{\text {th }}$ Malaysia plan to achieve major goals of: high income; inclusiveness; and sustainability (NEAM, 2010). Out of the eight strategic reform initiatives formulated in achieving the set goals, the second strategic reform is related to country's NHRD. It is about, "developing quality workforce and reducing dependency on foreign labour". (NEAM, 2010, p. 16). As a key pillar in the NEM, the '1Malaysia' concept addresses the first central challenge of vision 2020-' Establishing a united Malaysian nation made up of one Bangsa Malaysia with sense of common and shared destiny'. It aims to create strong and stable society as a precondition.

In its conceptualization, the 1Malaysia concept needs people to assimilate three principles of unity (acceptance, nationalistic principle, and social justice), two core values (mutual respect and humility), and eight aspirational values (Perseverance, acceptance, education, integrity, meritocracy, humility, loyalty, and culture of excellence). Therefore, 1Malaysia concept drives Malaysian societies for a cultural change that recognizes a 'people first' orientation while it urges to increase country's current performance through its last part of the slogan'performance now' in realizing vision 2020's aim to be a high income earned country. To instill these new values in all Malaysians and make them prepare for these new challenges, effective HRD efforts at national level are needed. NHRD as positioned by the pioneering authors deals with such issues pertaining to national level HRD to align people towards countries' future strategic requirements, aimed at development.

In the FORWARD of the Tenth Malaysia plan (2011-2015), it is highlighted the nation's critical limitation of human capital and talents in the nation, (Malaysia, 2010). Malaysia believes that the "foundation of any productive high-income nation lies in a globally competitive, creative and innovative workforce" (Malaysia, 2010, p. iv). In fulfilling this need, Malaysia has again understood its requirement to implement an integrated approach to address its critical HR limitation in nurturing, attracting, and retaining first-world talent base during the plan period (Malaysia, 2010, p. iv).

On the other hand, Malaysia, in its journey, has achieved a lot with respect to its human development. In 2020, Malaysia's Human Development Index (HDI) was 0.810 (UNDP, 2020) raising its position in $62^{\text {nd }}$ place out of 189 countries. During 1990 to 2019 Malaysia's HDI index increased by 26 percent. This report, however, further emphasized the needs to workout proper strategies and policies to achieve equity, sustainable development, eliminate increasing income inequalities, and combat the spread of HIV/AIDS and tuberculosis.

In the Malaysian context described above, it is clear that NHRD is needed in the realization of its development goals through the development of people's full potentials. There is evidence that national initiatives for such people development have been taken through its national planning by all government ministries/agencies/institutions in Malaysia. However, one can thus argue that Malaysia has to further strengthen its effort in NHRD in line with the perceived roles in the country's national policies and plans in order to realize its national goals and to resolve its national challenges. Malaysia therefore needs to be encouraged to 
understand the nature, constructions, conditions (pressures and imperatives), outcomes, and enablers and hindrances of its NHRD initiatives. Recommendation of required modifications to the existing HRD policies and practices can then be plausible in the achievement of the country's national goals.

\section{NHRD Literature Gap Identification}

Many authors have been debating over defining HRD since 1970s, yet traditional HRD was said to be narrowly defined (Weinberger, 1998) as it does not consider the variations in different country contexts and HRD phenomenon beyond organizational level (McLean and McLean, 2001) that commodified people to achieve performative goals (Snell and Wright, 2001; Wright and McMahan, 1992; Bierema, 2009). National HRD was first identified as a plausible solution to deal with this main limitation of traditional HRD (McLean, 2001) and defined to initiate a new research agenda (McLean, 2004). This research agenda was started with the evidence for the existence of NHRD practices, especially within the recently developed countries and transitioning societies (McLean, 2004; Cho and McLean, 2004; Devadas, 2016). However, there had been studies on NHRD phenomena even before the emergence of 'national human resource development as a separate field of study (Low, 1998; Cho and McLean, 2002; McLean, Bartlett and Cho, 2003; Ashton, 2002; Garavan, McGuire \& O'Donnell, 2004; Weick, 1995). The notable publications on HRD were continually found in the journals of: Advances in Developing Human Resources (ADHR) in 2004 (NHRD status and policies), 2006 (NHRD in transitioning societies), and 2012 (HRD for societal development) (Nagarathnam, 2016). Further, as reported by Nagarathnam (2016) a number of conceptual and empirical papers that focused on NHRD in different contexts were published in the premier HRD journals (Nagarathnam, 2016). Nagarathnam (2016) further justify with strong evidence of NHRD literature developments by citing NHRD scholarly work in other venues of NHRD dialogues, NHRD studies, done in terms of Human Capital Development. Devadas \& Silong (2010) reviewing HCD, HRD, and HD literature claimed that mere use of these terms interchangeably or equally in practice and in research may lead to misuse of the terms. Devadas and Silong further states that in the context of Malaysia, sufficient efforts have not been taken to identify what and how the terms such as HRD, HCD, and NHRD have been constructed until it is done in 2016 by Devadas as the first phase of this study. The challenges for and the contents and focus of NHRD in Malaysia, and the alternative terms, used in the context of Malaysia has been studied covering the period from 1950 to 2015 (Devadas, 2016). However, after 2015, how Malaysia has articulated the NHRD content, focus and its name have not been studied. Therefore, this current study, as the second phase of a longitudinal study further investigates the; context of Malaysia's NHRD planning, challenges for NHRD in Malaysia, the focus of NHRD in Malaysia, the contents of Malaysia's NHRD, and finally, the alternative terms, used for NHRD in the context of Malaysia after 2015 until a future planning period of 2030 .

\section{NHRD Theoretical Background}

The foundation of NHRD research agenda was laid by the Harbison and Mayer (H\&M)'s definition of HRD, given in 1964 (Paprock, 2006). H\&M had defined HRD within a larger context to help national economic development, not limiting to organizational performance. After such definitional roots of macro HRD, Mclean and McLean (2001) defined HRD first, in the global level and then at cross national level. A series of NHRD country case studies were done aligning to this global HRD definition. Major initiatives for NHRD theory development were taken with the NHRD country case studies. In 2004 and 2006, sixteen country case studies were done in emerging the NHRD research. These country case studies explored the NHRD's composition, the pressures and imperatives of NHRD, challenges to NHRD policy and its implementation, and supporting and inhibiting factors of NHRD. Another five country case studies on human capital 
development were published in 2009 and one case study in 2011. As the early models of NHRD theoretical models, Cho and McLean (2004) first developed five emerging models of NHRD, based on the 2004 country case studies, that were further intensified by Lynham and Cunningham (2006), based on 2006 country case studies. These five models are; centralized, transitioning, government initiated, decentralized, and small nation's models. The differences among these models have been presented by Devadas (2009). Nagarathnam (2016) also presents some NHRD models, developed apart from these major NHRD models. Nagarathnam (2016) further provides a NHRD policy framework that provides important insights into NHRD goals, stakeholders, NHRD process, and NHRD context with economic and finance conditions.

Cho and McLean (2004) have further identified some attributes of excellent NHRD and desirable outcomes of NHRD. Within the NHRD country case studies, Problems and Challenges for NHRD have been greatly discussed ( Roh, Ryu, and McLean, 2020; Torraco, and Lundgren, 2019; Rao, 2004; Hasler, Thompson, and Shuler, 2006; Cox, Arkoubi, and Estrada, 2006; LuttaMukhebi, 2004; Szalkowski and Jankowicz, 2004; Hawley and Paek, 2005; Bartlett and Rodgers, 2004; Wang and Wang, 2006; Li and Nimon, 2008; Lee, 2004; Cooper, 2004; Cho and McLean, 2004, Lynham and Cunningham, 2006; Devadas, 2009). Currently, NHRD theory development welcomes the new discoveries of NHRD practices in different country contexts.

\section{METHODOLOGY}

This study was done as a qualitative study mainly due to non-availability of literature in NHRD within Malaya. The research strategy was the content analysis, applying the grounded theory procedure in data analysis. The grounded theory was used as the data sources, and the selection of such data sources were also revealed as a part of the study and investigation. In otherward, this current study concurrently did the sampling and analysis which is encouraged by the grounded theory studies. Thus, the grounded theory approach was well matched with this study purpose. Malaysia's five year- national plans and Ten- year national policies were found as the main data sources in the national planning context of Malaysia. This study consisted of two phases; conceptualizing the meaning of NHRD in Malaysia covering the period from 2016 to 2030 by analyzing eleventh Malaysia plan and National Automation policy (NEP), and then integrating the current study findings with the first phase findings of the 2016 study, done for the period of 1950 to 2015, done by Devadas et.al. Thus, the two phases of the current study eventually covered a period from 1950 to 2030 to conceptualize Malaysia's NHRD for all time.

Grounded theory coding and constant comparison procedure governed the data analysis. Coding was done paragraph basis and entire section or chapter basis as allowed by Strauss \& Corbin, (1990). The main sections of national plans and national policies taken for the analysis were: the content pages; FORWARD; the very first chapters that describe the country's past performance, future prospects, plans' goals and objectives, and main challenges; and the chapters that described the human resource/ manpower / workforce / human capital development and education and training.

The coding process targeted at extracting information from the eleventh Malaysia plan and the NAP regarding national challenges, contents of national HRD, focus of national HRD, and the different terms used for national HRD. Each category was targeted to answer each research question. Thus, a priory coding has been used for the coding process that answers the research questions. Such an arrangement was prohibited by Glaser, (1992 and 1998). However, Strauss and Corbin (1998) allowed the researcher to do so. Therefore, the author wished to introduce the coding method used in this study as a 'selective coding' adopted in line with the pre-determined research questions and the research design. Then the constant comparison began to integrate two phases of the study. The comparison was done in two 
stages. All the final results were presented based on the conceptualizations, the themes generated for categories and the identified patterns emerged with the cording and the constant comparison methods. For the coding process, category map was used to support comparison, conceptualization, and theme building (Devadas, 2016). To enhance the quality of the study, the researcher used the exact terms used in the documents in developing the codes and coding, minimizing researcher bias to enhance validity, the emerging conceptualization was cross checked with the source documents for any deviation of meaning to enhance trustworthiness. The final conceptualization of 'the meaning of Malaysia's NHRD' was generated in two-time phases; in 2010 and 2021 with a high level of patience waiting for the completion of overall data. This claims that the study was really grounded in data by designing this as a longitudinal study. Besides, publication of the first phase outcomes, in an indexed journal, is a strong evidence of the justification of the validity, trustworthiness and credibility of this study in preserving the quality of the research.

\section{FINDINGS AND DISCUSSIONS}

\section{Context of NHRD plaining: Malaysia's National Planning and Policy Context with Leadership}

Malaysia planning system is consistent and cascading from long-term to medium-term and to short-term where the long-term planning prioritizes ten-year policies that in turn, lead to the strategic thrusts (directions) of the five-year plans, which then determine which projects receive funding in the annual budgets. Malaysia's planning episode can be presented as in Figure 02.

For the period from 1991 to 2010, like New Economic policy ten-year plan, National
Development Policy (NDP) was launched. To cover from 2011 to 2020, New Economic Model (NEM) was presented to expedite the achievement of vision 2020's late phase. In implementing the sustainable development agenda form 2015, the National Automotive Policy (NAP) was introduced in 2020 till 2030.

Under the directions of national policy context, Malaysia presents well-coordinated and integrated five-year plans (see Table 01). The national planning context in Malaysia has a well-integrated institutional leadership. Figure 3 and Figure 4 presents Malaysia's planning institutes and planning process. This centralized planning system, at federal government level, coordinates with the local governments in the preparation of plans through a top down approach in delivering and coordinating the execution of plans while a bottom up process is used to collect planning information feedback on plan executions.

In this study NHRD phenomenon is articulated within Malaysia's policy and national planning context. Malaysia has been succeeded in generating its ten-year policies and the five-year national plans continuously (Table 02). After, New economic model, Malaysia is yet to come up with policy framework, and the Twelfth Malaysia Plan in March 2021. Currently, National Automotive Policy, laid to boost the automotive industry in Malaysia has been regarded as its main economic framework. This is due to government's commitments towards NAP to eventually drive the economy towards high income earned society in realizing the vision of transforming Malaysia to achieve sustainable developments by 2050s (see figure 01). 
Malaysia: The planning timeline

\section{VISION AND STRATEGIC PRIORITIES}

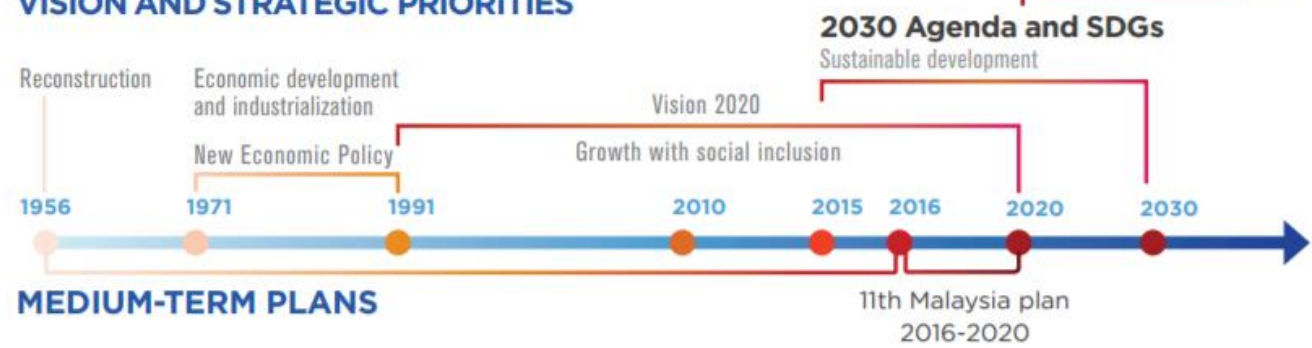

National

Transformation

Vision 2050

and SDGs

2016-2020

Figure 02: Malaysia Planning Horizon

Source: UNDP Sustainable Development Goals

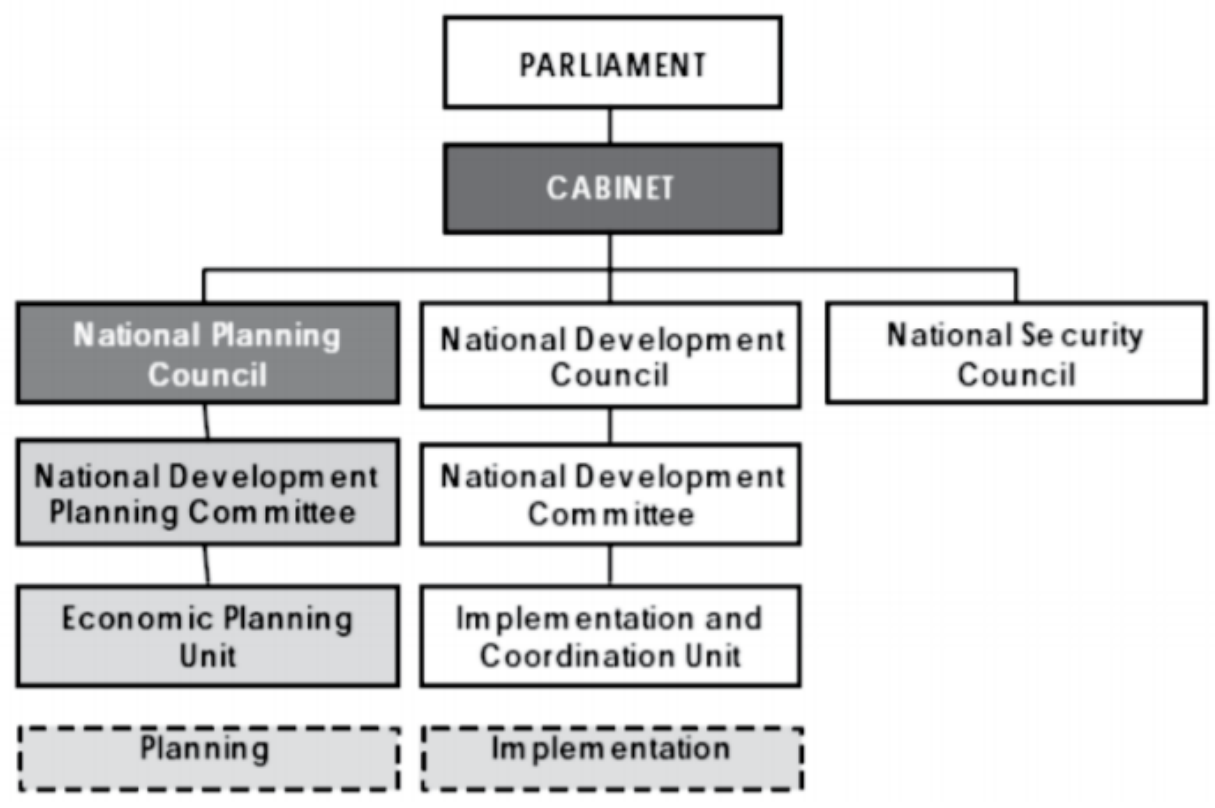

Figure 03- Malaysia Development Planning Institutes

Source: Lee and Lee, 2017, The Evolution of Development Planning in Malaysia, Southeast Asian Economies 
Table -01- Malaysia Planning Context-Five-year Development Plans

\begin{tabular}{|c|c|c|c|}
\hline Plan & Period & Goals & Challenges \\
\hline Draft Development Plan 1 & $1950-55$ & $\begin{array}{l}\text { Social services, infrastructure, } \\
\text { trade and development }\end{array}$ & $\begin{array}{l}\text { Emergency, 1948-60 } \\
\text { First elections, } 1955\end{array}$ \\
\hline First Malaya Plan & $1956-60$ & $\begin{array}{l}\text { Rural development, rubber } \\
\text { industry, emergency expenditure, } \\
\text { defence, security }\end{array}$ & $\begin{array}{l}\text { Independence, } 1957 \\
\text { Global recession, 1957-58 }\end{array}$ \\
\hline Second Malaya Plan & $1961-65$ & $\begin{array}{l}\text { Rural development, employment } \\
\text { generation, economic growth, } \\
\text { economic diversification, social } \\
\text { services }\end{array}$ & $\begin{array}{l}\text { Formation of Malaysia, } 1963 \\
\text { Separation of Singapore from } \\
\text { Malaysia, } 1965\end{array}$ \\
\hline First Malaysia Plan & $1966-70$ & $\begin{array}{l}\text { Racial harmony, economic } \\
\text { growth, employment generation, } \\
\text { economic diversification, } \\
\text { population planning }\end{array}$ & May 13 Riots, 1969 \\
\hline Second Malaysia Plan & $1971-75$ & $\begin{array}{l}\text { 1st Phase of NEP - eradication } \\
\text { of poverty, restructuring of } \\
\text { society } \\
\text { OPPI, 1971-90 }\end{array}$ & $\begin{array}{l}\text { New Economic Policy, 1971-90 } \\
\text { Oil shock, } 1973\end{array}$ \\
\hline Third Malaysia Plan & $1976-80$ & $\begin{array}{l}\text { 2nd Phase of NEP - eradication } \\
\text { of poverty, restructuring of } \\
\text { society } \\
\text { Private sector-driven }\end{array}$ & Oil shock, 1979 \\
\hline Fourth Malaysia Plan & $1981-85$ & NEP & Fiscal constraints, $1980-81$ \\
\hline $\begin{array}{l}\text { Mid-Term Review } \\
\text { Fourth Malaysia Plan }\end{array}$ & & $\begin{array}{l}\text { Revitalize agriculture sector } \\
\text { Privatization } \\
\text { Heavy industry }\end{array}$ & \\
\hline Fifth Malaysia Plan & 1986-90 & & Recession, 1985-86 \\
\hline Sixth Malaysia Plan & 1991-95 & $\begin{array}{l}\text { Sustain growth } \\
\text { Balanced development } \\
\text { Vision 2020 (1991) } \\
\text { OPP2, 1991-2000 } \\
\end{array}$ & $\begin{array}{l}\text { National Development Policy, } \\
1991-2000\end{array}$ \\
\hline Eighth Malaysia Plan & $2001-5$ & $\begin{array}{l}O P P 3,2001-10 \\
\text { Knowledge-based economy }\end{array}$ & $\begin{array}{l}\text { National Vision Policy, 2001- } \\
10\end{array}$ \\
\hline Ninth Malaysia Plan & $2006-10$ & $\begin{array}{l}\text { Value chain, human capital, } \\
\text { socio-economic inequities }\end{array}$ & $\begin{array}{l}\text { Global Financial Crisis, } 2008 \\
\text { 12th General Election (2008) } \\
\text { National Mission, 2006-20 }\end{array}$ \\
\hline Tenth Malaysia Plan & $2011-15$ & $\begin{array}{l}\text { Government Transformation } \\
\text { Programme } \\
\text { New Economic Model } \\
\text { Economic Transformation } \\
\text { Programme }\end{array}$ & $\begin{array}{l}\text { Global financial crisis } \\
\text { Greater competition for FDI } \\
\text { Weak private investment }\end{array}$ \\
\hline Eleventh Malaysia Plan & $2016-20$ & $\begin{array}{l}\text { Inclusiveness, well-being, } \\
\text { infrastructure, green growth }\end{array}$ & $\begin{array}{l}\text { 13th General Elections (2013) } \\
\text { Fiscal constraints } \\
\text { Deindustrialization } \\
\text { Malaysian National } \\
\text { Development Strategy }\end{array}$ \\
\hline
\end{tabular}

Source: Lee and Lee, 2017, The Evolution of Development Planning in Malaysia, Southeast Asian Economies 


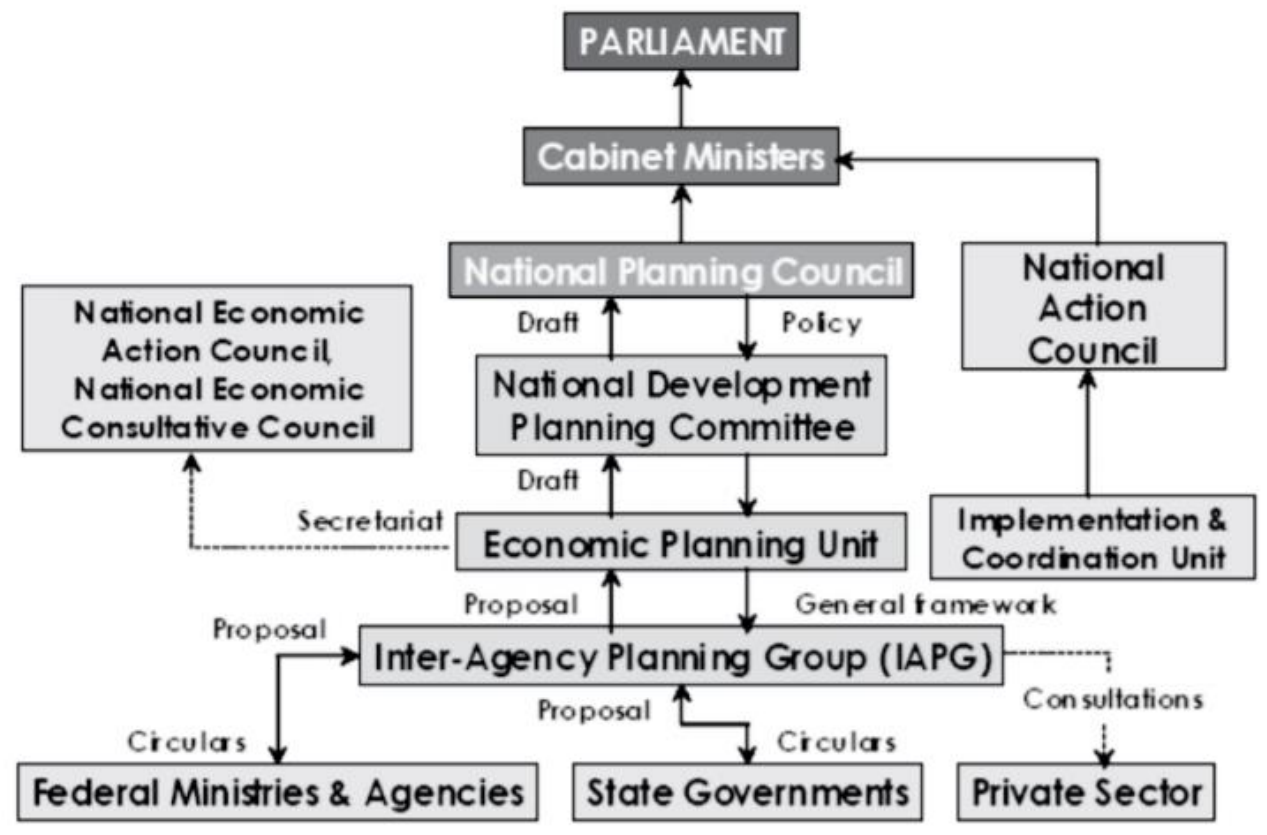

Figure 04- Malaysia Development Planning Process

Source: Lee and Lee, 2017, The Evolution of Development Planning in Malaysia, Southeast Asian Economies

Table -02- Relationships between Malaysia's National Policies and Plans

\begin{tabular}{|c|c|c|}
\hline National policy & Policy Purpose & Five-year plans included \\
\hline $\begin{array}{l}\text { Pre-NEP period (1060- } \\
\text { 1970) } \\
\text { Developed Import } \\
\text { Substitute Policies }\end{array}$ & $\begin{array}{l}\text { Import substitution and Agri } \\
\text { based development }\end{array}$ & $\begin{array}{l}\text { First Malaysia Plan (1960- } \\
\text { 1970) }\end{array}$ \\
\hline $\begin{array}{l}\text { New economic Policy } \\
\text { (NEP)- (1971-1990) }\end{array}$ & $\begin{array}{l}\text { Concerned about Equity } \\
\text { sharing among Malaysians } \\
\text { and non-Malaysians while } \\
\text { targeting for export-oriented } \\
\text { growth }\end{array}$ & $\begin{array}{ll}\text { Second Malaysia } & \text { Plan } \\
(1971-1975) & \\
\text { Third Malaysia } & \text { Plan } \\
\text { (1976-1980) } & \\
\text { Fourth Malaysia } & \text { Plan } \\
\text { (1981 to 1985) } & \\
\text { Fifth Malaysia Plan (1986- } \\
\text { 1990) }\end{array}$ \\
\hline $\begin{array}{ll}\text { National } & \text { Development } \\
\text { Policy (NDP) (1991-2000) }\end{array}$ & $\begin{array}{l}\text { Becoming a developed } \\
\text { nation economically, } \\
\text { politically, socially, } \\
\text { psychologically, spiritually, } \\
\text { culturally. } \\
\text { Vision } 2020 \text { was laid down }\end{array}$ & $\begin{array}{l}\text { Sixth Malaysia Plan (1991- } \\
\text { 1995) } \\
\text { Seventh Malaysia Plan } \\
(1996-2000)\end{array}$ \\
\hline $\begin{array}{l}\text { National Vision } \\
\text { (NVP) }(2001-2010)\end{array}$ & $\begin{array}{l}\text { Establishing a united, } \\
\text { progressive and prosperous }\end{array}$ & $\begin{array}{l}\text { Eighth Malaysia } \\
\text { (2001-2005) }\end{array}$ \\
\hline
\end{tabular}




\begin{tabular}{l|l|ll}
\hline & $\begin{array}{l}\text { Bangsa* Malaysia by } \\
\text { building a resilient and } \\
\text { competitive nation, and } \\
\text { equitable society with the } \\
\text { overriding objective of } \\
\text { National Unity. }\end{array}$ & $\begin{array}{l}\text { Ninth Malaysia Plan } \\
(2006-2010)\end{array}$ & \\
\hline New Economic Model & $\begin{array}{l}\text { Doubling the per capita } \\
\text { income to realize vision } \\
\text { (NEM) 2011-2020 }\end{array}$ & $\begin{array}{l}\text { Tenth Malaysia Plan } \\
(2011-2015) \\
\text { approach becoming more } \\
\text { competitive, market and } \\
\text { investor-friendly. }\end{array}$ & $\begin{array}{l}\text { (2016-2020) } \\
\text { Nalaysia Plan }\end{array}$ \\
\hline National Automation Policy & $\begin{array}{l}\text { Was laid in 2020 21 } \\
\text { February 2020 targeting at } \\
\text { developing Malaysia's } \\
\text { automotive industry as a } \\
\text { global player to boost } \\
\text { economic development }\end{array}$ & $\begin{array}{l}\text { Twelfth Malaysia Plan to } \\
\text { be tabled in March 2021 }\end{array}$ & \\
\end{tabular}

Bangsa Malaysia means, Malaysian nation. Bangsa means nation.

Source: Authors development on policy content observations

Table -03 Malaysia's National Challenges for 1950 to 2015

\begin{tabular}{|c|c|c|c|}
\hline Core theme based on national plans & $\begin{array}{l}\text { Core themes based } \\
\text { on national } \\
\text { policies }\end{array}$ & $\begin{array}{l}\text { Core theme } \\
\text { derived from } \\
\text { comparison }\end{array}$ & $\begin{array}{l}\text { Core theme for } \\
\text { Malaysia's } \\
\text { national challenge }\end{array}$ \\
\hline $\begin{array}{l}\text { Ensuring equitable, society with } \\
\text { balanced development, progressing } \\
\text { towards high income economy } \\
\text { successfully facing the external } \\
\text { environmental uncertainties in } \\
\text { gaining economic power in Asia }\end{array}$ & $\begin{array}{l}\text { Ensuring national } \\
\text { unity and } \\
\text { inclusiveness with } \\
\text { equitable society } \\
\text { progressing } \\
\text { towards high } \\
\text { income economy } \\
\text { successfully facing } \\
\text { the external } \\
\text { environmental } \\
\text { uncertainties to } \\
\text { gain a globally } \\
\text { competitive edge }\end{array}$ & $\begin{array}{l}\text { Ensuring equitable } \\
\text { society with } \\
\text { reduced socio- } \\
\text { economic } \\
\text { disparities, } \\
\text { progressing } \\
\text { towards high } \\
\text { income economy } \\
\text { successfully facing } \\
\text { the external } \\
\text { environmental } \\
\text { uncertainties to } \\
\text { gain a global } \\
\text { competitive edge }\end{array}$ & $\begin{array}{l}\text { Ensuring national } \\
\text { unity and } \\
\text { inclusiveness with } \\
\text { equitable and } \\
\text { stable society, } \\
\text { progressing } \\
\text { towards a high } \\
\text { income economy } \\
\text { successfully facing } \\
\text { the external } \\
\text { environmental } \\
\text { uncertainties in } \\
\text { gaining a } \\
\text { competitive global } \\
\text { edge }\end{array}$ \\
\hline
\end{tabular}

Source: Devadas, 2016

\section{Malaysia's National Challenges}

Based on the category maps, developed to code Malaysia's national plan, two outcome sets were generated. First, to conceptualise Malaysia's contemporary National Challenges (table 03) for the period from 2016 to 2030. Second, to integrate these outcomes with the phase one outcome done in 2016 to cover a period from 1950 to 2015, thematizing Malaysia's national challenges for all time from 1950 to 2030 (table 04). With the combination of contemporary views and the historic view of Malaysia national Challenges, table-04 can summarize the overall national challenges of Malaysia for all-time. 
Table -04 Malaysia' Contemporary National challenges from 2016 to 2030

\begin{tabular}{|c|c|c|c|}
\hline $\begin{array}{l}\text { National } \\
\text { Challenges of in } \\
\text { the Eleventh } \\
\text { Malaysia plan } \\
\text { From 2016 to2020 }\end{array}$ & $\begin{array}{l}\text { National Challenges as } \\
\text { per the NAP } \\
\text { From } 2020 \text { to } 2030\end{array}$ & Comparison & $\begin{array}{l}\text { Contemporary } \\
\text { Challenges of } \\
\text { Malaysia } \\
\text { (from 2016 to 2030) }\end{array}$ \\
\hline $\begin{array}{l}\text { Continued } \\
\text { uncertainties in the } \\
\text { global economy; the } \\
\text { prospect of low } \\
\text { prices for crude oil } \\
\text { and other major } \\
\text { commodities; the } \\
\text { risk of a slowdown } \\
\text { in the economies of } \\
\text { major trading } \\
\text { partners; low } \\
\text { stimulus to boost } \\
\text { productivity, } \\
\text { strengthen the fiscal } \\
\text { position and } \\
\text { adequate public } \\
\text { funding, and to raise } \\
\text { the average income } \\
\text { and share of total } \\
\text { income of the } \\
\text { bottom } 40 \% \\
\text { household income } \\
\text { group to become } \\
\text { truly inclusive (11 th } \\
\text { Plan, p.7) }\end{array}$ & $\begin{array}{l}\text { Significant challenges } \\
\text { faced by the automotive } \\
\text { industry such as } \\
\text { regional agreements, } \\
\text { territory rights, on-tariff } \\
\text { barriers, consolidations, } \\
\text { production of luxury } \\
\text { goods; globalization, } \\
\text { economic liberalization } \\
\text { and increasing } \\
\text { competition, (NAP, } \\
\text { p.28) }\end{array}$ & $\begin{array}{l}\text { Globalization and } \\
\text { uncertainties in the } \\
\text { global economy; } \\
\text { economic } \\
\text { liberalization and } \\
\text { increasing } \\
\text { competition, the } \\
\text { prospect of low } \\
\text { prices for crude oil } \\
\text { and other major } \\
\text { commodities; the risk } \\
\text { of a slowdown in the } \\
\text { economies of major } \\
\text { trading partners; low } \\
\text { stimulus to boost } \\
\text { productivity, } \\
\text { strengthen the fiscal } \\
\text { position and adequate } \\
\text { public funding, to } \\
\text { raise the average } \\
\text { income and share of } \\
\text { total income of the } \\
\text { bottom } 40 \% \\
\text { household income } \\
\text { group to become } \\
\text { truly inclusive; } \\
\text { Significant } \\
\text { challenges faced by } \\
\text { the automotive } \\
\text { industry such as } \\
\text { regional agreements, } \\
\text { territory rights, non- } \\
\text { tariff barriers, } \\
\text { consolidations, } \\
\text { production of luxury } \\
\text { goods. }\end{array}$ & $\begin{array}{l}\text { Uncertain global } \\
\text { economies with } \\
\text { economic } \\
\text { liberalization, } \\
\text { increased } \\
\text { competition } \\
\text { prospects of low } \\
\text { prices for major } \\
\text { commodities, } \\
\text { slowdown of major } \\
\text { trading partners, low } \\
\text { stimuli to boost } \\
\text { productivity, } \\
\text { strengthening fiscal } \\
\text { position and } \\
\text { funding, and raising } \\
\text { income of all needy } \\
\text { people, and } \\
\text { automotive industry } \\
\text { specific challenges. }\end{array}$ \\
\hline
\end{tabular}

Source: Author's research findings 
Table -05- National Challenges of Malaysia for all time from 1950 to 2030.

\begin{tabular}{|c|c|c|c|}
\hline $\begin{array}{l}\text { National Challenges } \\
\text { of Malaysia from } \\
1950 \text { to } 2015\end{array}$ & $\begin{array}{l}\text { Common theme for } \\
\text { Malaysia's } \\
\text { contemporary } \\
\text { national challenges }\end{array}$ & Comparison & $\begin{array}{l}\text { Malaysia's national } \\
\text { challenges for all } \\
\text { time } \\
(1950-2030)\end{array}$ \\
\hline $\begin{array}{l}\text { Ensuring national } \\
\text { unity and } \\
\text { inclusiveness with } \\
\text { equitable and stable } \\
\text { society, progressing } \\
\text { towards a high- } \\
\text { income economy } \\
\text { successfully facing } \\
\text { the external } \\
\text { environmental } \\
\text { uncertainties in } \\
\text { gaining a } \\
\text { competitive global } \\
\text { edge }\end{array}$ & $\begin{array}{l}\text { Uncertain global } \\
\text { economies with } \\
\text { economic liberalization, } \\
\text { increased competition } \\
\text { prospects of low prices } \\
\text { for major commodities, } \\
\text { slowdown of major } \\
\text { trading partners, low } \\
\text { stimuli to boost } \\
\text { productivity, } \\
\text { strengthening fiscal } \\
\text { position and funding, } \\
\text { and raising income of } \\
\text { all needy people, and } \\
\text { automotive industry } \\
\text { specific challenges. }\end{array}$ & $\begin{array}{l}\text { Global } \\
\text { Environmental } \\
\text { uncertainties with } \\
\text { economic } \\
\text { liberalization, } \\
\text { increased competition } \\
\text { prospects of low } \\
\text { prices for major } \\
\text { commodities, } \\
\text { slowdown of major } \\
\text { trading partners, low } \\
\text { stimuli to boost } \\
\text { productivity, } \\
\text { strengthening fiscal } \\
\text { position and funding, } \\
\text { and raising income of } \\
\text { all needy people, and } \\
\text { automotive industry } \\
\text { specific challenges; } \\
\text { gaining competitive } \\
\text { global edge, ensuring } \\
\text { national unity and } \\
\text { inclusiveness with } \\
\text { equitable and stable } \\
\text { society, progressing } \\
\text { towards a high- } \\
\text { income economy } \\
\text { successfully }\end{array}$ & $\begin{array}{l}\text { Global uncertainness } \\
\text { creating local } \\
\text { economic fluctuations } \\
\text { and constraints that } \\
\text { reduce } \\
\text { competitiveness, } \\
\text { leading low income } \\
\text { sharing among needy } \\
\text { people that reduce } \\
\text { inclusiveness creating } \\
\text { troubles ensuring } \\
\text { national unity in } \\
\text { creating equitable and } \\
\text { stable society in } \\
\text { progressing towards } \\
\text { high income economy. }\end{array}$ \\
\hline
\end{tabular}

Source: Author's development based on research findings

\section{Focus of Malaysia's NHRD}

Under the focus of NHRD in Malaysia, the researcher explored for which main purposes NHRD missions have been launched as explained in the national planning context. Based on the category maps, developed to code Malaysia's national plan, two outcome sets were generated. First, to conceptualise Malaysia's contemporary focus of its NHRD missions (table 06) for the period from 2016 to 2030. Second, to integrate these outcomes with the phase one outcome done in 2016 to cover a period from 1950 to 2015 , thematizing
Malaysia's focus of its NHRD missions for all time from 1950 to 2030 (table 07). Devadas (2016), reports the focus of Malaysia's NHRD for the period from first to tenth Malaysia plans, covered by NEP, NDP, and NEM. Accordingly, its focus is 'developing, maintaining a high-quality human resource in order to fulfill the economic requirements in resolving the national challenges" (p.129). the contemporary focus of NHRD during the eleventh plan and the NEP period can be interpreted based on the comparison done in table 07. 
Table-06-Contemporary focus of Malaysia's NHRD-2016-2030

\begin{tabular}{l}
\hline $\mathbf{1 1}^{\text {th }}$ Plan' NHRD focus \\
\hline Improving labour market \\
efficiency to accelerate economic \\
growth
\end{tabular}

Transforming TVET to meet industry demand

Strengthening lifelong learning for skills enhancement

Improving the quality of education for better student outcomes and institutional excellence $11^{\text {th }}$ plan, $\mathrm{p} 127-158$ )

NAP' $s$ NHRD focus

Promote establishment of Industry 4.0 Academy for automotive sector.

Continuation of Automotive Apprenticeship Programme to accelerate the intakes

Uniformize, review and promote the creation of new TVET programs in line with the current industry requirements,

Improve existing automotive related education Programme in line with current trend and industry needs.

Enforce mandatory accreditation for automotive and mobility ecosystem workforce

Continuation of fund allocation under Automotive Industry Development Programme (AIDP).by January 2021. under IR4.0 of graduates into the industry.

\section{Contemporary focus}

Improving labour market

efficiency, transforming TVET to meet industry demand, strengthening lifelong learning for skills enhancement, improving the quality of education for better student outcomes and institutional excellence, enhancing capabilities in the automotive industry by enhancing education and training of automotive sector, standardizing accreditation of automotive and mobility ecosystem

Workforce, and funding for

Automotive Industry

Development

Programme (AIDP).

Source: Author's development based on research findings

Table -07- All Time Focus of Malaysia's NHRD-1950-2030

\begin{tabular}{|c|c|c|}
\hline Contemporary focus of NHRD & Historic focus of NHRD & All time focus of NHRD \\
\hline $\begin{array}{l}\text { Improving labour market } \\
\text { efficiency, transforming TVET to } \\
\text { meet industry demand, } \\
\text { strengthening lifelong learning } \\
\text { for skills enhancement, } \\
\text { improving the quality of } \\
\text { education for better student } \\
\text { outcomes and institutional } \\
\text { excellence, enhancing capabilities } \\
\text { in the automotive industry by } \\
\text { enhancing education and training } \\
\text { of automotive sector, } \\
\text { standardizing accreditation of } \\
\text { automotive and mobility } \\
\text { ecosystem } \\
\text { Workforce, and funding for } \\
\text { Automotive Industry } \\
\text { Development } \\
\text { Programme (AIDP). }\end{array}$ & $\begin{array}{l}\text { 'developing, maintaining a high- } \\
\text { quality human resource in order } \\
\text { to fulfill the economic } \\
\text { requirements in resolving the } \\
\text { national challenges" }\end{array}$ & $\begin{array}{l}\text { developing, maintaining a high- } \\
\text { quality human resource in order } \\
\text { to fulfill the national economic } \\
\text { and specific industry } \\
\text { requirements in resolving } \\
\text { national challenges by improving } \\
\text { labour market conditions; and } \\
\text { enhancing education, training, } \\
\text { learning, and accreditations }\end{array}$ \\
\hline
\end{tabular}

Source: Author's Development 
In comparison of contemporary NHRD focus with the historic focus of NHRD, the focus of NHRD in all time in Malaysia, can be interpreted for the period from 1950 to 2030 (Table 07).

\section{The Content of Malaysia's NHRD}

Devadas (2016), reports the content of Malaysia's NHRD for the period from first to tenth Malaysia plans, covered by NEP, NDP, and NEM. Accordingly, its content is 'managing the work force, talent \& human capital development (education and skill training), and labour market reforms'. (p.126). the contemporary content of NHRD during the eleventh plan and the NEP period can be interpreted based on the comparison done in Table 08 .

In comparison of contemporary NHRD content with the historic focus of NHRD, the focus of NHRD in all time in Malaysia, can be interpreted for the period from 1950 to 2030 (Table 09).

Table -08- contemporary Content of Malaysia's NHRD-2016-2030

\begin{tabular}{|c|c|c|}
\hline 11 ${ }^{\text {th }}$ Plan' NHRD Content & NAP's NHRD Content & Contemporary Content \\
\hline $\begin{array}{l}\text { National and industry labour } \\
\text { markets development; } \\
\text { National and industry-based } \\
\text { education development; } \\
\text { National and Industry based } \\
\text { workforce training, } \\
\text { development and enhancing } \\
\text { accreditations; and enhancing } \\
\text { life-long learning }\end{array}$ & $\begin{array}{l}\text { Education, training and } \\
\text { learning in the automotive } \\
\text { industry courses, automotive } \\
\text { industry workforce training } \\
\text { and accreditation, and } \\
\text { automotive industry labour } \\
\text { market development. }\end{array}$ & $\begin{array}{l}\text { National and industry level } \\
\text { HRD. } \\
\text { Education development, } \\
\text { lifelong learning, workforce } \\
\text { development and } \\
\text { accreditations, and labour } \\
\text { market development. }\end{array}$ \\
\hline
\end{tabular}

Source: Author's development based on research findings

Table-09-All Time Content of Malaysia's NHRD-1950-2030

\begin{tabular}{l|l|l}
\hline $\begin{array}{l}\text { Contemporary Content of } \\
\text { NHRD }\end{array}$ & Historic Content of NHRD & All time Content of NHRD \\
\hline $\begin{array}{l}\text { National and industry level } \\
\text { HRD. }\end{array}$ & $\begin{array}{l}\text { 'managing the work force, } \\
\text { talent \& human capital } \\
\text { development (education and } \\
\text { skill training), and labour } \\
\text { market reforms'. }\end{array}$ & $\begin{array}{l}\text { managing the work force, } \\
\text { talent \& human capital } \\
\text { development through national } \\
\text { and industry-based education } \\
\text { and training, and labour } \\
\text { market reforms and } \\
\text { development' }\end{array}$ \\
$\begin{array}{l}\text { Education development, } \\
\text { develong learning, workforce } \\
\text { accreditations, and labour } \\
\text { market development }\end{array}$ & & \\
\hline
\end{tabular}

Source: Author's development based on research findings

\section{Alternative Terms, Used for NHRD in Malaysia}

As Devadas (2016) observes, during the period from 1950 to 2030, in the first Malaysia plan, the term Human Resource Development has been used to deal with human resource at national level. In each plan, the terms used for $\mathrm{HRD}$, is evolving from 'population, labor force and man power development' to 'human capital and talent development'. This reflects the focus of Malaysia's HRD from 'managing quantity of human resource' to 'managing the quality of human resource by expressing National HRD in Malaysia during that period as 'Human Capital Development (HCD)'. Identifying how it is termed in the contemporary context, the eleventh plan and the NAP were analyzed. In the Eleventh plan, the term used for NHRD is 'human capital development' (11 $1^{\text {th }}$ Malaysia, p. 127). The NAP presents it as 'Human Capital 
Development'. It is clear that, contemporarily, NHRD in Malaysia has been labeled as 'human capital development'. With the comparison between historic view and the contemporary view of NHRD in Malays, it can be said that in all time from 1950 to 2030, Malaysia's NHRD has been termed as 'human capital Development'.

\section{CONCLUSION, IMPLICATIONS, AND RECOMMENDATIONS}

This longitudinal study, covering a period from 1950 to 2030 under two research phases in 2016 and 2021, constructed a meaning of Malaysia's national HRD by identifying its major contents, focus, national challenges, and the terms used for NHRD in Malaysia. This study remained only at national planning level, applying the grounded theory canons and procedures in data analysis. Accordingly, this study concludes that Malaysia NHRD includes areas coming under human capital development, driven through a properly coordinated national planning system. It further, considers organizational, industry and national level aspects of HRD. Malaysia's NHRD mainly focus on enhancing the quality of human capital of the country in order to achieve national development goals, especially the economic development goals, and to resolve Malaysia's national challenges. The term used for NHRD in Malaysia, though changed during early times, human capital development has been identified as the appropriate label for NHRD in Malaysia in common.

This implicates that, Malaysia's NHRD efforts, in general, performative to achieve national development goals and plays a critical role in country's development. This will demand a proper mechanism to measure the success of NHRD planning and execution. Trends to connect Malaysia's NHRD with its economic development priorities in the recent times, may hinder the balance development of Malaysia's people holistically, creating barriers for other aspects of people development specially, the areas suggested by UNDP's sustainable development goals.
It is recommended, therefore, to take right actions in streamlining its national planning system for proper coordination in NHRD planning and execution activities to make the overall NHRD process effective. It is further needed to integrate non-economic human development perspectives to be connected with the main streamline of its human capital development to sustain overall human development in the country. Further, satisfactory initiatives to be taken to absorb the UNDP's sustainable development goals in the mainstream of Malaysia's human capital development missions, again to balance the development of economic and non-economic aspects of people development.

This construction is useful in many ways for the researchers and for the practitioners as such efforts to identify the meaning of Malaysia' national HRD has not been made here before through a formal investigation except some guess works. Hence, this study stimulates a series of studies to investigate planning and implementation of national HRD with its clarified focus and to identify the pressures and imperatives for them. Further, this discovery can greatly contribute to the NHRD research agenda in testifying the models that have already been developed based on the country case studies. On the other hand, defining Malaysia's NHRD is now possible while letting a high-level comparison of Malaysia's NHRD with other countries in the region and in the world. Since now the focus of Malaysia's NHRD is cleared by this study, practitioners may use this to coordinate their national HRD efforts with more confidence of its final expectations and outcomes. Since this study was limited to the national policies and plans, the findings need to be verified by the views of the planners and the practitioners to enhance the theoretical validity of the conceptualizations.

\section{REFERENCES}

Ashton, D. (2002). Explaining Change in National HRD Strategies: The case of three Asian Tigers. The European Journal of Development Research, 4, (1), 126-144. 
Bartlett, K. R., \& Rodgers, J. (2004). HRD as a National Policy in the Pacific Islands. Advances in Developing Human Resources, 6(3), 307-314. doi: $10.1177 / 1523422304266078$

Bierema, L. L. (2009). Critiquing Human Resource Development's Dominant Masculine Rationality and Evaluating Its Impact. Human Resource Development Review. 8(1), 68-96

Cho E. S. and McLean G.N. (2002). National Human RD: Korean Case. In U. Pareek, A.M. Osman-Gani, S. Ramnaravan \& T.V. Rao (Eds.) HRD in Asia: Trends and Challenges (pp253-260), New Delhi, India: Oxford \& IBH

Cho, E., \& McLean, G. N. (2004). What we discovered about NHRD and What it means for HRD. Advances in Developing Human Resources, 6(3), 382393.doi:10.1177/1523422304266090

Cho, E., \& McLean, G. N. (2004). What we discovered about NHRD and What it means for HRD. Advances in Developing Human Resources, 6(3), 382393.doi:10.1177/1523422304266090

Cooper, S. (2004). National Governance and Promising Practices in Workplace Learning: A Postindustrial Programmatic Framework in Canada. Advances in Developing Human Resources, 6(3), 363-273. doi: $10.1177 / 1523422304266088$

Cox, J. B., Arkoubi, K. A., \& Estrada, S. D. (2006). National Human Resource Development in Transitioning Societies in the Developing World: Morocco. Advances in Developing Human Resources, 8(3), 8498. doi:10.1177/1523422305283068

Devadas, (2016). Does Malaysia Practice National Human Resource Development, Journal of Management Policy and Practice Vol. 17(2) 2016115

Devadas, U.M. and Silong, A.D. (2009). Problems and challenges of national human resource development in the development of developing countries. International
Conference on Development 2009 conference proceedings, (pp. 23), Kula Lumpur: International Islamic University.

Devadas, U.M., Silong, A.D. Development of Human Capital Theory, Proceedings of the International Conference of Academy of $H R D$ (Asia Chapter), Shanghai, China, Nov.11-14, 2010. Osman-Gani, A.M. and Jian, H.; ECNU Graduate Program of HRDE: Shanghai, 2010.

Devadas, U.M., Silong, A.D., Crauss S.E., and Ismail, I.A. (2012). From Human Resource Development to National Human Resource Development: Resolving Contemporary HRD Challenges, Pertanika Journal of Social Science and Humanities, 20(2), p.359-374.

Economic Planning Unit (EPU) (2010). Human Capital Development in Malaysia: Performance, Challenges and Way Forward. Prime Minister's Department

Economic planning unit, (2017). Midterm review of the Eleventh Malaysia Plan 20162020, Prime ministers' department: https://www.epu.gov.my/en/economicdevelopments/development-plans/rmk/midterm-review-eleventh-malaysia-plan-20162020

Economic Planning Unit. (2011). Vision 2020, 1991-2020. Retrieved on March 03, 2012, from http://www.epu.gov.my/184

FAOU. (2020). Global Forest Resource Assessment 2020 Report Malaysia. http://www.fao.org/3/cb0033en/cb0033en.p df. Accessed: 17/02-2021

Garavan, T.N., McGuire, D. M., \& Donhell, D.O. (2004). Exploring Human Resource Development: A Level of analysis Approach. Human Resources Development Review, 3, (4), 417-441

Glaser, B. G. (1992). Basics of Grounded Theory Analysis. Mill Valley: Sociology Press.

Glaser, B. G. (1998). Doing Grounded Theory: Issues and Discussions. Mill Valley: Sociology Press. 
Hasler, M. G., Thopmson, M. D., \& Schuler, M. (2006). National Human Resource Development in Transitioning Societies in the Developing World: Brazil. Advances in Developing Human Resources, 8(1), 99-115.

Hawley, J. D., \& Paek, J. (2005). Developing human resources for the technical workforce: a comparative study of Korea and Thailand. International journal of training and development, 9(1), 79-94.

Lee, M. (2004) National Human Resource Development in the United Kingdom. Advances in Developing Human Resources,6(3), 334-345.

Lee, S., and Lee, C.G. (2017). The Evolution of Development Planning in Malaysia, Journal of Southeast Asian Economies, Vol.34, 03, pp. 436-461. DOI: DOI: 10.1355/ae34-3b.

file:///C:/Users/Mohan/Downloads/JSEAE Dec2017LeeLee\%20(1).pdf

Li, J., and Nimon, K. (2008). The importance of recognizing generational differences in HRD Policy and practices: A study of workers in Qinhuangdao, China. Human Resource Development International,11(2), 167-182.

Low, L. (1998). Human Resource Development in the Asia-Pacific. AsianPacific Economic Literature, 12, (1), 27-40.

Lutta-Mukhebi, M.C. (2004). National Human Resource Development policy in Kenya. Advances in Developing Human Resources, 6(3), 326-333.

Lynham, S.A. and Cunningham, P.W. (2006) National Human Resource Development in Transitioning Societies in the Developing World: Concept and Challenges. Advances in Developing Human Resources, 8(1), 11627.

Malaysia. (1966). First Malaysia Plan, 1966-1970. Kuala Lumpur, Malaysia: National Printing Department.

Malaysia. (1971). Second Malaysia Plan, 1971-1975. Kuala Lumpur, Malaysia: National Printing Department.
Malaysia. (1976). Third Malaysia Plan, 1976-1980. Kuala Lumpur, Malaysia: National Printing Department.

Malaysia. (1981). Fourth Malaysia Plan, 1981-1985. Kuala Lumpur, Malaysia: National Printing Department.

Malaysia. (1986). Fifth Malaysia Plan, 1986-1990. Kuala Lumpur, Malaysia: National Printing Department.

Malaysia. (1991). Sixth Malaysia Plan, 1991-1995. Kuala Lumpur, Malaysia: National Printing Department.

Malaysia. (1996). Seventh Malaysia Plan, 1996- 2000.Kualar Lumpur, Malaysia: Percetakan national Malaysia Berhad.

Malaysia. (2001). Eighth Malaysia Plan, 2001 - 2005. Putrajaya, Malaysia: Government Printing Press.

Malaysia. (2006). Ninth Malaysia Plan, 2006 2010. Putrajaya, Malaysia: Government Printing Press.

Malaysia. (2010). Tenth Malaysia Plan, 20112015.Putrajaya, Malaysia: Government Printing Press.

Malaysia. (2011). Eleventh Malaysia Plan, 2016- 2020.Putrajaya, Malaysia: Government Printing Press.

McLean, G. N., \& McLean, L. (2001). If we can't define HRD in one country, how can we define it in an international context? Human Resource Development International, 4(3), 313-326.

McLean, G.N. (2004). National Human Resource Development: What in the World is it? Advances in Developing Human Resources, 6, (3), 269-275.

McLean, G.N., Bartlett, K., \& Cho, E.S. (2003). Human RD as national policy: Republic Korea and New Zealand, pacificAsian education journal, 15, (1), 41-59.

Mehan, N. (2011, December). Strategic HRD and post training interventions for greater return on investments. In Sulaiman, M. (Chair). Capitalizing on Human Expertise 
for Greater Innovation and Creativity. Keynote Speech made at 10th AHRD conference, Kula Lumpur, Malaysia.

Nagarathnam, B.B. (2016). National human resource development: review of research and a framework for practice (Doctoral dissertation),

https://core.ac.uk/download/pdf/79654777.p df

National Economic Advisory Council (NEAM) (2010). New Economic Model for Malaysia-Part 1. Kuala Lumpur: Percetakan National Malaysia Berhad.

Paprock, K. E. (2006). National Human Resource Development in Transitioning Societies in the Developing World: Introductory Overview. Advances in Developing Human Resources, 8(12), 11-26

Rao, T. V. (2004). Human Resource Development as National Policy in India. Advances in Developing Human Resources, 6(3), 288-296.

Roh, K., Ryu, H., and McLean, G.N. (2020). Analysis of national human resource development (NHRD) policies of 2016 in South Korea with implications, European Journal of Training and Development, Retrieved:

https://www.emerald.com/insight/publicatio n/issn/2046-9012

Snell, S.A., \& Wright, P. (2001). Human Resource and the Resource based of the firm. Journal of Management, 27, 701-721.

Strauss, A. L. and Corbin, J (1990). Basics of qualitative research: Grounded theory procedures and techniques, London, Sage.

Strauss, A.L. and Corbin, J (1998). Basics of qualitative research: Techniques and procedures for developing grounded theory", (2nd ed.). Newbury Park, CA: Sage.

Szalkowski, A., and Jankowicz, D. (2004) The Development of Human Resources During the Process of Economic and Structural Transformation in Poland. Advances in Developing Human Resources, (6)3, 346354.
Torraco, R.J. and Lundgren, H. (2019). What HRD Is Doing-What HRD Should be Doing: The Case for Transforming HRD, Human Resource Development Review, Retrieved:

https://doi.org/10.1177/1534484319877058

UNDP, (2020). Good Practices Integrating SDGS into Development Planning: Malaysia, UNDP Sustainable Development Goals:

file:///C:/Users/Mohan/Downloads/Malaysi a\%20Good\%20Practices\%20(2).pdf

UNDP, (2020). Malaysia Human Development Report, https://www.google.com/search?q=HDI+m alaysia\%2C+undp\&oq=HDI+malaysia $\% 2 \mathrm{C}$ +undp\&aqs $=$ chrome.69i57.10098j0j15\&sou rceid $=$ chrome $\&$ ie $=\mathrm{UTF}-8$

Wang, J., \& Wang, G. G. (2006). Exploring National Human Resource Development: A Case of China Management Development in a Transitioning Context. Human Resource Development Review, 5(2), 176-183. doi:10.1177/1523422305283055

Weick, K.E. (1995). What theory is not, theorizing is? Administrative Science Quarterly, 40(3), 385-390. Retrieved from doi: $10.2307 / 2393789$

Weinberger, L.A. (1998). Commonly held theories of human resource development. Human Resource Development International, $\quad 1(1), \quad 75-93$. doi:10.1080/13678869800000009

Wright, P. M., \& McMahan, G. C. (1992). Theoretical perspectives for strategic human resource management. Journal of Management, $\quad 18, \quad$ (2), 295320.www.macrothink.org/ijhrs Doi:10.5296/ijhrs. v4i1.5303 URL: http://dx.doi.org/10.5296/ijhrs.v4i1.5303 